\title{
THE ROLE OF SOFT LAW IN THE CONVERGENCE OF PENSION POLICIES OF EU MEMBER STATES
}

\author{
UDC 364.35(4-672EU)
}

\author{
Milena Nikolić \\ Faculty of Economics, University of Niš, Republic of Serbia
}

\begin{abstract}
The failure of the European Union to harmonize the pension policies of its Member States and tighten the policy of budget deficit and public debt control have intensified the efforts to find a new way to regulate this area. Instead of harmonizing the Member States' pension policies, the European Union has decided to take action aimed at their convergence. Given that the great heterogeneity of the Member States' pension systems and policies made the implementation of the hard law infeasible, soft law has been implemented for regulating this area. The aim of this paper is to determine the effect of soft law regulation on the convergence of pension policies of the European Union Member States and assess its impact on the achievement of common defined objectives: sustainability and adequacy of pension systems, as well as modernization of pension systems.
\end{abstract}

Key words: soft law, reform, convergence, pension policy, European Union

\section{INTRODUCTION}

A high degree of autonomy of the European Union Member States in the area of social and pension policies has contributed to a large heterogeneity of their pension systems. Thus, the pension systems of Member States differ nowadays according to the pension model under whose influence they have been developing, the types of pension plans, the funding method, as well as the numerous institutional and organizational characteristics. Nevertheless, most Member States have a common feature: dominant public pay as you go pension systems, which are becoming financially unsustainable in contemporary conditions. Since budget funds have been used for a long period of time to cover the deficit of the pension system, this has significantly affected the levels of budget deficit and the public debt in numerous Member States. There is a great concern on the national and European levels that these pension systems will threaten the fiscal stability of Member States and lead to a new economic and financial crisis.

Received November $15^{\text {th }}, 2016 /$ Accepted July $6^{\text {th }}, 2017$

Corresponding author: Milena Nikolić, LL.M, PhD Student

Faculty of Ecnomics, University of Niš, Trg Kralja Aleksandra 11, 18000 Niš, Republic of Serbia

E-mail: milenanikolic1983@yahoo.com 
The efforts made to harmonize the pension systems of Member States have not provided the expected results. The pension policy is still under the full jurisdiction of Member States; therefore, direct implementation of hard law in this area is impossible. The European Union indirectly affected the reform of pension systems by establishing fiscal criteria within the Maastricht Treaty, by introducing rules for managing sound finances and coordination of fiscal policies of Member States within the Stability and Growth Pact, as well as by determining Broad Economic Policy Guidelines (BEPG) in Member States. In this way, the European Union pointed out to the Member States that in their budgets there would not be any more funding of deficits of public pension systems and that they need to be reformed, but it still did not contribute to the harmonization of Member States' pension systems.

At the turn of the $21^{\text {st }}$ century, efforts have been intensified in the European Union to find a new way for regulating this area. Instead of harmonizing the pension policy of Member States, the European Union decided to undertake activities aimed at their convergence. In order to accomplish these goals, soft law started being implemented.

This paper analyzed the impact of soft law on the convergence of pension policies of the EU Member States. The paper first focuses on the definition of the term soft law, its characteristics and the role it has in the European Union law. The second part is dedicated to the use of an open method of coordination and its influence on the development of pension policies of Member States. In the final part, contribution of the Green and White Papers to the convergence of pension policies of Member States is analyzed.

\section{SOFT LAW AND ITS ROLE IN THE EUROPEAN UNION LAW}

The origin of soft law may be traced back to the 1970s, when it was developed and conceptualized in the area of international public law in USA (Zerilli, 2010: 9). In Europe, it was affirmed at the end of the $20^{\text {th }}$ century, by adopting the Principles of European Contract Law in 1995 and the UNIDROIT Principles of International Commercial Contracts in 1994 (Đurđev, 2013: 104). It has been applied in numerous areas of international law: commerce, banking, insurance, arbitration, environment protection, human rights and other areas (Đurđev, 2013: 104; Zerilli, 2010: 9).

There is much controversy in legal literature in terms of the legal nature of soft law and, accordingly, there are many definitions of this law. Due to different and opposing opinions of authors who have dealt with this issue, three movements (schools of thought) have developed: positivist, rationalist and constructivist (Avramović, 2011: 275) (Shaffer, Pollack, 2010: 707). Authors belonging to the positivist movement do not consider soft law to be a law because it is legally non-binding (Shaffer, Pollack, 2010: 707, 713). Some believe that the obligations which arise from it are neither soft nor hard, because they are not law at all (Weil, 1983: 415). Rationalist-oriented authors are less critical than positivists; they emphasize that hard and soft laws can exist at the same time and they claim that a country chooses one or the other depending on the context (Shaffer, Pollack, 2010: 707; Đurđev, 2013: 104). Snyder belongs to this group of authors who believe that these are rules of conduct which do not have a legally binding power but still produce some legal consequences in the practical sense (Snyder, 1993: 32; Đurđev, 2013: 104105). Then, there are authors who point out the reasons why soft law has supremacy in comparison to hard law, which is due to its greater flexibility, faster implementation, 
lower costs, being less threatening to the national sovereignty, etc. (Guzman, 2005: 591592; Abbott, Snidal, 2000: 423, 434). The constructivist movement arose owing to authors who emphasize the advantages of this source of law; they point out that it can be used in order to achieve better results than those that can be achieved through hard law, reminding that most international law is soft in a certain way (Đurđev, 2013: 104-105; Abbott, Snidal, 2000: 421). They consider that it is not important if soft law is formally binding or not, but rather whether the instruments of this law are efficient (Avramović, 2011: 276).

Irrespective of how soft law is defined, it has multiple significant implications in practice. Soft law can influence the development of hard law, that is, it can be a kind of preparation for this law, whereby it has a pre-law function (Peters, Pagotto, 2004: 22-24, 28; Shelton, 2003: 10). Besides, soft law can be used as a supplement to hard law, or for its interpretation, when it represents a law-plus function. Furthermore, it can be a substitute for hard law, that is, it can have a para-law function (Shelton, 2003: 10; Peters, Pagotto, 2004: 22-24, 28).

Soft law has a particularly significant role in the European Union law. Due to its flexibility and non-binding nature, it is a favourable instrument for adjusting the Member States' pension policies. It is mostly used for creating global law and denationalization on the global level, and it is created by numerous international organizations: the Organization for Economic Cooperation and Development, the World Trade Organization, the International Monetary Fund, the World Bank (Zerilli, 2010: 8-9), the European Commission and other European institutions. The most common sources of soft law in the European Union law are recommendations and opinions, strategies, declarations, White papers, Green papers, announcements, communications, charters, etc. (Đurđev, 2013: 106-110).

The sources of soft law in the European Union law have been mostly used in sensitive areas, that is, in policies where Member States do not want to give up their jurisdictions, which is the case in pension policies. At times when population is rapidly aging and when baby boom generations are expected to retire, the harmonization of pension policies of Member States is inevitable because the increase of expenditures for pensions in public pension systems negatively affects their fiscal stability (Schulz, 2001: 284-288; Clark, Burkhauser, Moon, Quinn, Smeeding, 2004: 29; Rakić, Nikolić, 2011: 404-406). The instruments of soft law have been used after the adoption of the Lisbon Strategy, with the aim of harmonizing the Member States pension policies. The open method of coordination, the Green and White Papers have stood out up to now as the most significant instruments of soft law in pension policy.

\section{IMPLEMENTATION OF THE OPEN METHOd OF COORDINATION IN PENSION POLICY}

The open method of coordination is one of the most significant instruments of soft law in the area of social and pension policies. The origins of this method may be found way back in the Maastricht Treaty (1991), when new methods for coordination of policies in the area of economic and monetary unions were used, as well as in the employment policy implemented in 1997, when the Amsterdam Treaty introduced the European Employment Strategy (Szyszczak, 2006: 486). Yet, the most important inspiration for establishing this method was the Luxembourg Summit in 1997 which identified the need for a European Employment Strategy, which contained the concept of the open method of 
coordination - guidelines, best practices and goals which were adapted to national specificities (Dehousse, 2003: 5). Finally, the adoption of the Lisbon Strategy in 2000 contributed for the most part to the affirmation of this method, by which two goals of the European Union were established: the improvement of European competitiveness and the development of a European model of social protection (Borrás, Jacobsson, 2004: 189-190); thus, the open method of coordination was formally introduced as the new instrument of convergence in the area of social policy (De la Rosa, 2005: 618). After only a period of one year, this method was being applied in the pension policy (Eckardt, 2005: 248).

Designed as a flexible, politically led, non-regulatory instrument, which is based on a partial delegation of power, the open method of coordination was considered appropriate for harmonizing pension policies of Member States (Borrás, Jacobsson, 2004: 199). The implementation of this method implies a complex process of coordination, which consists of several phases (Lisbon European Council, 2000; De la Porte, 2002: 40):

1. Fixing guidelines for the Union, combined with specific timetables for achieving the goals which the Member States set in the short, medium and long terms;

2. Establishing, where appropriate, quantitative and qualitative indicators and benchmarks against the best in the world and tailored to the needs of different Member States and sectors, as a means of comparing best practices;

3. Translating these European guidelines into national and regional policies by setting specific targets and adopting measures, taking into account national and regional differences. In concrete terms, the policy reform actions of the Member States are integrated into their National Actions Plans (NAPs) periodically;

4. Periodic monitoring, evaluation and peer review, organized as mutual learning processes.

Determining common goals (guidelines) is of primary importance for the initiation of this process. The most important goals of pension policy are: adequacy, financial sustainability and modernization of pension systems, which were formulated at the Göteborg European Council in 2001, as follows (Commission of the European Communities, 2001: 3):

1. Adequacy - to safeguard the capacity of pension systems to meet their social aims of providing safe and adequate incomes to retired persons and their dependants, and to ensure, in combination with health and long-term care systems, decent living conditions for all elderly persons;

2. Financial sustainability - to ensure the financial sustainability of pension systems so that the future impact of ageing does not jeopardise the long-term sustainability of public finances or the ability to meet fundamental goals of budgetary policy (in terms of overall tax burdens or spending priorities) and does not lead to an unfair sharing of resources between generations;

3. Modernization - to enhance the capacity of pension systems to respond to the changing needs of the society and individuals, thereby contributing to enhanced labour market flexibility, equal opportunities for men and women with regard to employment and social protection, and a better adaptation of pension systems to individual needs.

Starting from these common goals, 11 specific goals were identified which Member States should strive towards in the reform of their pension systems (Table 1). 
Table 1 Common and specific goals of the open method of coordination

\begin{tabular}{ll}
\hline Common goals & Specific goals \\
\hline \multirow{3}{*}{ Adequacy } & 1. Prevent social exclusion \\
& 2. Enable people to maintain living standards \\
& 3. Promote solidarity \\
Financial & 4. Raise employment levels \\
sustainability & 5. Extend working lives \\
& 6. Make pension systems sustainable in a context of sound public finances \\
& 7. Adjust benefits and contributions in a balanced way \\
& 8. Ensure that private pension provision is adequate and financially sound \\
Modernization & 9. Adapt more flexible employment and career patterns \\
& 10. Meet the aspirations for greater equality of women and men \\
& 11. Demonstrate the ability of pension systems to meet the challenges \\
\hline
\end{tabular}

Unlike the goals which were clearly defined, indicators were not determined immediately. At first, only a few indicators of adequacy and financial sustainability of the pension system were determined (Eckardt, 2005: 254), while the remaining indicators were determined only several years later, which created a basis for monitoring the progress in achieving the envisaged goals (Table 2).

Table 2 The list of primary indicators of streamlined pension portfolio

\begin{tabular}{ll}
\hline Streamlined goals & Primary indicators \\
\hline $\begin{array}{l}\text { Adequate } \\
\text { pensions }\end{array}$ & $\begin{array}{l}\text { 1. At-risk-of-poverty rate of older people } \\
\text { 3. Aggregate replacement ratio }\end{array}$ \\
& $\begin{array}{l}\text { 4. Change in projected theoretical replacement ratio for base case 2006- } \\
\text { 2046 accompanied with information on type of pension scheme (DB, DC } \\
\text { or NDC) and change in projected public pension expenditure 2006-2046 }\end{array}$ \\
\hline $\begin{array}{l}\text { Sustainable } \\
\text { pensions }\end{array}$ & $\begin{array}{l}\text { 5. Total current pension expenditure (\% of GDP) } \\
\text { 7. Effective labour market exit age }\end{array}$ \\
\hline $\begin{array}{l}\text { 8. Projections of pension expenditure, public and total, 2004-2050 } \\
\text { (\% of GDP) }\end{array}$ \\
pensions
\end{tabular}

Indicators are grouped according to each of the mentioned common goals. Considering that the number of determined indicators is large, this paper presents only the primary ones, which cover the most important dimensions of the defined goals and/or maintain the social situation of a crucial segment of population. Aside from these primary indicators, there are the secondary ones which support the primary ones by providing better insight into the nature of the problem as well as the environment indicators, which give information about the past and future movements in the environment in which a pension system of a concrete country functions (European Commission, 2009: 3-4). Among these indicators, there are 
EU indicators, which are used for comparative analysis of Member States, as well as national indicators, which are not used for comparative analysis but they provide information which is significant for determining their progress in achieving these goals (European Commission, 2009: 3-4).

After determining the common goals and indicators for monitoring their implementation, the coordination process implies the design of national strategic reports (National Actions Plans - NAPs), which are submitted to the European Commission by individual countries. The European Commission reviews and evaluates the submitted reports, and then makes a joint report in which problems and best practices are identified and recommendations for the reform of pension systems are made.

The established coordination process within the open method of coordination is the result of joint work of a large number of participants: the European Union, Member States, different actors on the regional and local levels. A wide range of participants provides for the collection of various ideas and innovations in the pension policy, which most frequently occur on the local and national levels, and afterwards spread bottom up through this coordination network (Eckardt, 2005: 258-261). The exchange of information about the methods of reform, experiences and achieved results enables the identification of good practices and measures which are applicable in similar circumstances for handling similar problems in pension systems of other countries, such as continuous learning with very low costs of information collection. Although the open method of coordination is often criticized for its non-binding character, for insufficient influence on change of pension policies of Member States and for being behind in determining indicators and descriptive national reports of Member States, the contribution of this method to the development of the pension policy is significant because it accelerates the reform of pension systems of the EU Member States and the formulation of their national pension policies (Eckardt, 2005: 258-262).

\section{CONTRIBUtion OF the GREen AND White PAPERS TO THE CONVERGENCE of PENSION POLICIES OF MEMBER STATES}

The beginning of the second decade of the $21^{\text {st }}$ century has been marked by the emergence of new sources of soft law in the pension area - the Green and White Papers. The Green Paper has initiated the discussion on adequacy, sustainability and safety of European pension systems. Envisaging a holistic approach to the reform of pension systems, this book considers key challenges encountered by the pension systems of Member States and the ways in which the European Union can provide support for accomplishing the envisaged goals. Changes in pension systems and the effect of the economic and financial crisis are highlighted as key challenges and priorities in modernization of the pension policy in the European Union, primarily including the realization of adequate and sustainable pensions, establishing a balance between the time spent at work and in pension, removing obstacles to mobility of labour force in the European Union, and creating safe and transparent pensions (European Commission, 2010: 2-16.). The Commission also underscored the need to improve the European statistics on pensions, as well as the need to update the management of pension policy on the level of the European Union (European Commission, 2010: 16-17). After the publication of the Green Paper, all relevant and interested parties were called to respond 
to the questions posed about all these topics in this paper; in such a way, a discussion about adequate, sustainable and safe pension systems was initiated.

Two years later, as a result of the discussion initiated by the Green Paper, the White Paper was published as an agenda and a kind of strategy for attaining adequate, safe and sustainable pensions. Moreover, the White Paper emphasizes the challenges of pension systems and points out to the necessity of reforming European pension systems and developing instruments at the European Union level which will affect national pension systems of Member States. A particularly important part of this Paper is the one including recommendations to Member States for the reform of the pension system, particularly those related to establishing balance between the years spent at work and the years spent in retirement, and the development of complementary private retirement savings. Specifically, the recommendations are as follows (European Commission, 2012: 9-13):

1. Link the retirement age with increases in life expectancy;

2. Restrict access to early retirement plans and other early exit pathways;

3. Support longer working lives by providing a better access to life-long learning, adapting working places to a more diverse workforce, developing employment opportunities for older workers and supporting active and healthy aging;

4. Equalise the retirement age for men and women;

5. Support the development of complementary retirement savings to enhance retirement incomes.

Increasing the retirement age and linking it with increases in life expectancy is of great significance for the creation of a sustainable pension system. Its decrease in the second half of the $20^{\text {th }}$ century, without the analysis of demographic, economic and social-political changes, significantly harmed the functioning of public pension systems, which are funded pay as you go. Nowadays, when these pension systems are making huge deficits of funds for pension payments, it is impossible to expect high pension benefits with such a low retirement age and shortened working life. In order for pension benefits to be higher, it is necessary to extend working life in accordance with increase in life expectancy, and to continue adjusting it in the future (Schwan, Sail, 2013: 12; European Commission, 2012: 10). The past experiences of Member States indicate that the increase in the working life is possible also by increasing years of service needed for obtaining the right to full pension or by relating the length of years of service with the life expectancy, then by linking pension benefit levels with the increase of life expectancy, as well as their connection to the financial balance of the pension plan (European Commission, 2012: 10).

In order to extend the working life, besides raising the mandatory retirement age or years of service (which is necessary for its further adjustment with increase in life expectancy), it is also necessary to reduce early retirement. This can be achieved by closing pension plans which offer the possibility of early retirement or reducing the levels of pension benefits, which are provided by such pension plans, and by providing opportunities for changing jobs to workers who perform arduous and hazardous jobs (European Commission, 2012: 11). These measures may lead to increasing the effective retirement age.

The increase in the working life in accordance with the increase in life expectancy cannot be achieved unless measures for providing support to older workers are taken. The most important support measures refer to improving the health of the elderly through investment in prevention of illness, promotion of healthy and active aging, providing access to life-long learning, adapting working places to the needs of older workers and developing of opportunities for flexible work engagement (by providing part-time jobs and opportunities for partial retirement) (European Commission, 2012: 11-12). 
Eliminating the retirement gap between men and women is a very significant measure, both in terms of ensuring the stability of the pension system and providing adequate pension benefits for women upon retirement. Equalising the retirement age for men and women contributes to raising the participation of older worker in the labour force, and it affects the increase of pension benefits for women based on a greater number of years of service (European Commission, 2012: 12). In addition to the retirement age, it is important to eliminate the differences between men and women in employment, labour payments, paid contributions and years of service, which arise from the fact that women have always been in charge of raising children and taking care of the elderly in the family (European Commission, 2010: 9; European Commission, 2012: 12).

Besides the guidelines explaining how to establish a balance between the length of working life and the length of retirement periods, there are important guidelines referring to the development of complementary private retirement savings. In order to develop this type of savings and secure the future adequacy of pensions, it is necessary to take measures for reducing costs in these pension plans, increasing safety and providing an equal access to pension plans for all (European Commission, 2012: 12). In this area, the European Union has established a specific regulatory framework by adopting the Directive on the Protection of Employees in the Event of Insolvency of Their Employer (2008) and the Directive on the Activities and Supervision of Institutions for Occupational Retirement Provision - IORP (2003). However, it is necessary to additionally improve the IORP Directive (European Commission, 2010: 10-14; European Commission, 2012: 1213). It can be achieved by supplementing it with provisions which would enable crossborder mobility of workers in Member States, without losing the entitlements to private pension insurance, establishing a service for recording these entitlements and the ones obtained in public pension plans, improving the quality of financial products for individual retirement savings and other financial products which can increase pensioners' benefits, providing clear and relevant information and improving protection of pensioners (European Commission, 2010: 10-16; European Commission, 2012: 12-13).

\section{CONCLUSION}

Despite the frequent criticism of soft law and the denial of legitimacy of these sources and their instruments, their contribution to the convergence of pension policies of Member States cannot be disputed. The significance of the open method of coordination and the Green and White Papers for Member States pension system reforms is considerable.

The implementation of the open method of coordination, as a new flexible instrument of convergence in the Member States' pension policies, has enabled the collection of important information on current and future problems in this area. The results of the taken measures point to numerous opportunities for the pension systems reform. The creation of a database with free access available to all countries provided for the possibility of identifying examples of good practice and experiences of these countries in applying various measures, which is significant for the reform of pension systems of other Member States and the ones pursuing the EU membership. On the other hand, the challenges and priorities which are presented in the Green Paper and the White Paper, along with the recommendations to Member States for pension systems reform, create a good basis for further development of the Member States' pension policies. The exchange of 
experience about reform within the coordinated process, which is initiated by implementing the open method of coordination and adjusting the Member States' pension policies to other recommendations, can contribute to a certain convergence of the Member States' pension policies towards the goals which have been determined at the European Union level.

At times when most Member States and the countries aspiring to become EU Member States are facing great pressure of pensioners, who are an increasingly numerous election body, the influence of international institutions on the development of pension policy is very important in view of achieving the defined goals. Although soft law does not envisage sanctions for failing to meet these goals, and particularly given the absence of hard law which cannot yet be applied in this area, soft law still exerts some pressure and creates expectations, which ultimately affect the reform of the Member States' pension systems.

\section{REFERENCES}

Abbott, K.W., Snidal, D., (2000). Hard and Soft Law in International Governance, International Organization, Vol. 54, No. 3, pp. 421-456, doi: 10.1162/002081800551280.

Avramović, D., (2011). „Omekšavanjem prava“ ka međunarodnoj vladavini prava?, Srpska politička misao, Vol. 32, No. 2, pp. 263-288.

Borrás, S., Jacobsson, K., (2004). The Open Method of Co-ordination and New Governance Patterns in the EU, Journal of European Public Policy, Vol. 11, No. 2, pp. 185-208,

doi: 10.1080/1350176042000194395.

Clark, R.L., Burkhauser, R.V., Moon, M., Quinn, J.F., Smeeding, T.M., (2004). The Economics of an Aging Society, Oxford, Blackwell Publishing.

Commission of the European Communities, (2001). Supporting National Strategies for Safe and Sustainable Pensions Through an Integrated Approach, Brussels, Retrieved 26.02. 2016 from http://eurlex.europa.eu/legal-content/EN/TXT/PDF/?uri=CELEX:52001DC0362\&from=EN.

Dehousse, R., (2003). The Open Method of Coordination: A New Policy Paradigm?. Les Cahiers européens de Sciences Po, No. 03/2003, Paris, Centre d'etudes européennes at Sciences Po, Retrieved 20 February 2016 from https://core.ac.uk/download/pdf/6564112.pdf.

De la Porte, C., (2002). Is the Open Method of Coordination Appropriate for Organising Activities at European Level in Sensitive Policy Areas?, European Law Journal, Vol. 8, No. 1, pp. 38-58.

De la Rosa, S., (2005). The Open Method of Coordination in the New Member States: The Perspectives for its Use as a Tool of Soft Law, European Law Journal, Vol. 11, No. 5, pp. 618-640.

Đurđev, D., (2013). Soft Law u evropskom komunitarnom pravu, Zbornik radova Pravnog fakulteta u Novom Sadu, Vol. 1, pp. 101-116. doi: 10.5937/zrpfns47-3383.

European Commission, (2012). White Paper: An Agenda for Adequate, Safe and Sustainable Pensions, Brussels, European Commission.

European Commission, (2010). Green Paper: Towards Adequate, Sustainable and Safe European Pension Systems, Brussels, European Commission.

European Commission, (2009). Portfolio of Indicators for the Monitoring of the European Strategy for Social Protection and Social Inclusion - 2009 Update. Brussels, European Commission.

Eckardt, M., (2005). The Open Method of Coordination on Pensions: An Economic Analysis of its Effects on Pension Reforms, Journal of European Social Policy, Vol. 15, No. 3, pp. 247-267, doi: $10.1177 / 0958928705054088$

Guzman, A. T., (2005). The Design of International Agreements, The European Journal of International Law, Vol. 16, No. 4, pp. 579-612, doi: 10.1093/ejil/chi134.

Lisbon European Council, (2000). Lisbon European Council of 23 and 24 March 2000, Presidency Conclusions, Retrieved 15 February 2016 from www.europarl.europa.eu/summits/lis1_en.htm.

Natali, D., (2008). Pensions in Europe, European Pensions: The Evolution of Pension Policy at National and Supranational Level, P.I.E. Peter Lang S.A, Brussels.

Peters, A., Pagotto, I., (2004). Soft Law as a New Mode of Governance: A Legal Perspective, NewGov. Project No. CIT1-CT-2004-506392, Retrieved 10 March 2016 from https://ius.unibas.ch/uploads/publics/3940/ 20100219145119_4b7e9757829c2.pdf. 
Rakić, B., Nikolić, M., (2011). Uticaj demografskih kretanja na sisteme penzionog osiguranja/ In Aranđelović, Z. (ed), Regionalni razvoj i demografski tokovi zemalja jugoistočne Evropel. - Niš: Ekonomski fakultet, 2011, pp. 403-413.

Schulz, J.H., (2001). The Economics of Aging, Greenwood Publishing Group, London.

Schwan, A., Sail, E., (2013). Assessing the Economic and Budgetary Impact of Linking Retirement Ages and Pension Benefits to Increase in Longevity. European Economy - Economic Papers 512. Brussels: European Commission.

Shaffer, G.C., Pollack, M.A., (2010). Hard vs. Soft Law: Alternatives, Complements and Antagonists in International Governance, Minnesota Law Review, Vol. 94, No. 3, pp. 706-799.

Shelton, D., (2003). Introduction: Law, Non-Law and the Problem of 'Soft Law'/ In Shelton, D. (ed), Commitment and Compliance: The Role of Non-binding Norms in the International Legal System/.- New York, Oxford University Press, pp. 1-18.

Snyder, F., (1993). The Effectiveness of European Community Law: Institutions, Processes, Tools and Techniques, The Modern Law Review, Vol. 56, No. 1, pp. 19-54.

Szyszczak, E., (2006). Experimental Governance: The Open Method of Coordination, European Law Journal, Vol. 12, No. 4, pp. 486-502.

Weil, P., (1983). Towards Relative Normativity in International Law?, The American Journal of International Law, Vol. 77, No. 3, pp. 413-442.

Zerilli, F.M. (2010). The Rule of Soft Law: An Introduction. Focaal-Journal of Global and Historical Anthropology. Vol. 56. 3-18. doi:10.3167/fcl.2010.560101.

\section{ULOGA MEKOG PRAVA U KONVERGENCIJI PENZIJSKIH POLITIKA ZEMALJA ČLANICA EU?}

Neuspeh Evropske unije da harmonizuje penzijsku politiku svojih članica i pooštravanje kontrole visine budžetsko deficita i javnog duga, intenzivirali su napore da se pronađe nov način za regulisanje ove oblasti. Umesto harmonizacije penzijske politike zemalja članica, Evropska unija je odlučila da aktivnosti usmeri na njihovu konvergenciju. S obzirom na to da je zbog velike heterogenosti penzijskih sistema $i$ penzijskih politika zemalja članica primena tvrdog prava (hard law) bila nemoguća, za regulisanje ove oblasti počelo je da se primenjuje meko pravo (soft law). Cilj ovog rada je da se utvrdi uticaj mekog prava na konvergenciju penzijskih politika zemalja članica, odnosno njegov uticaj na ostvarenje zajednički utvrđenih ciljeva penzijske politike - održivosti i adekvatnosti penzijskih sistema, kao i modernizacije penzijskih sistema.

Ključne reči: meko pravo, reforma, konvergencija, penzijska politika, Evropska unija 